\title{
Green synthesis of 4-methoxybenzylidene thiazole derivatives using potassium carbonate as base under ultrasound irradiation
}

\author{
Dattatraya N. Pansare ${ }^{\mathrm{a}^{*}}$, Rohini N. Shelke ${ }^{\mathrm{a}}$, Chandraknat D. Pawar ${ }^{\mathrm{b}}$, Aniket P. Sarkate ${ }^{\mathrm{b}}$, Pravin N. \\ Chavan $^{c}$, Shankar R. Thopate ${ }^{d}$ and Devanand B. Shinde ${ }^{e}$
}

${ }^{a}$ Department of Chemistry, Deogiri college, Station road, Aurangabad 431 005, MS, India

${ }^{b}$ Department of Chemical Technology, Dr. Babasaheb Ambedkar Marathwada University, Aurangabad-431 004, MS, India

${ }^{c}$ Department of Chemistry, Doshi Vakil College, Goregaon, District-Raigad, (MS), India

${ }^{d}$ Department of Chemistry, S.S.G.M. College, Kopargaon, Ahmednagar, (MS), India

${ }^{e}$ Shivaji University, Vidyanagar, Kolhapur, 416004, MS, India

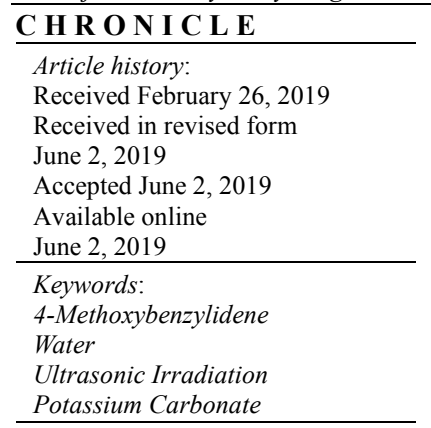

\begin{abstract}
A B S T R A C T
An environmentally benign aqueous protocol for the synthesis of novel 2-((5-(4methoxybenzylidene)-4-oxo-4,5-dihydrothiazol-2-yl)amino)substituted acid by using potassium carbonate as a base has been achieved. These ultrasound irradiation and conventional technique reaction proceed efficiently in water in the absence of organic solvent. In comparison with conventional methods, our protocol is convenient and offers several advantages, such as shorter reaction time, higher yields, milder conditions and environmental friendliness.
\end{abstract}

\section{Introduction}

The Nitrogen-containing five and six-member heterocyclic compounds and their derivatives, which can be easily synthesized in laboratories, are particularly important and often found in natural sources. The 2-thioxothiazolidin-4-one (Rhodanine) based molecules and thiazole have been reported to exhibit a broad spectrum of biological activities, such as anti-inflammatory, ${ }^{1,2}$ antipyretic, ${ }^{3,4}$ antidiabetic, ${ }^{5}$ anticancer, ${ }^{6}$ antitubercular, ${ }^{7,8}$ anti-HIV ${ }^{9-11}$ antiparasitic, ${ }^{12}$ hypnotic ${ }^{13}$ and antiproliferative agents. ${ }^{14,15}$ Rhodanine was discovered in 1877 , so there have been several attempts to design antimicrobial agents based on this heterocycles. There are various reports available on rhodanine derivatives as antimicrobial agents. ${ }^{16-21}$ These reports suggested that a chain containing free carboxyl group at rhodanine nuclei was important to the observed levels of biological activity ${ }^{22}$ and synthesized structures of rhodanine containing moiety is shown (Fig. 1).

* Corresponding author. Fax: +91 0240-2400413, Mobile no. +91 9850108474 E-mail address: dattatraya.pansare7@gmail.com (D. N. Pansare)

(C) 2019 by the authors; licensee Growing Science, Canada

doi: $10.5267 /$ j.ccl.2019.006.001 


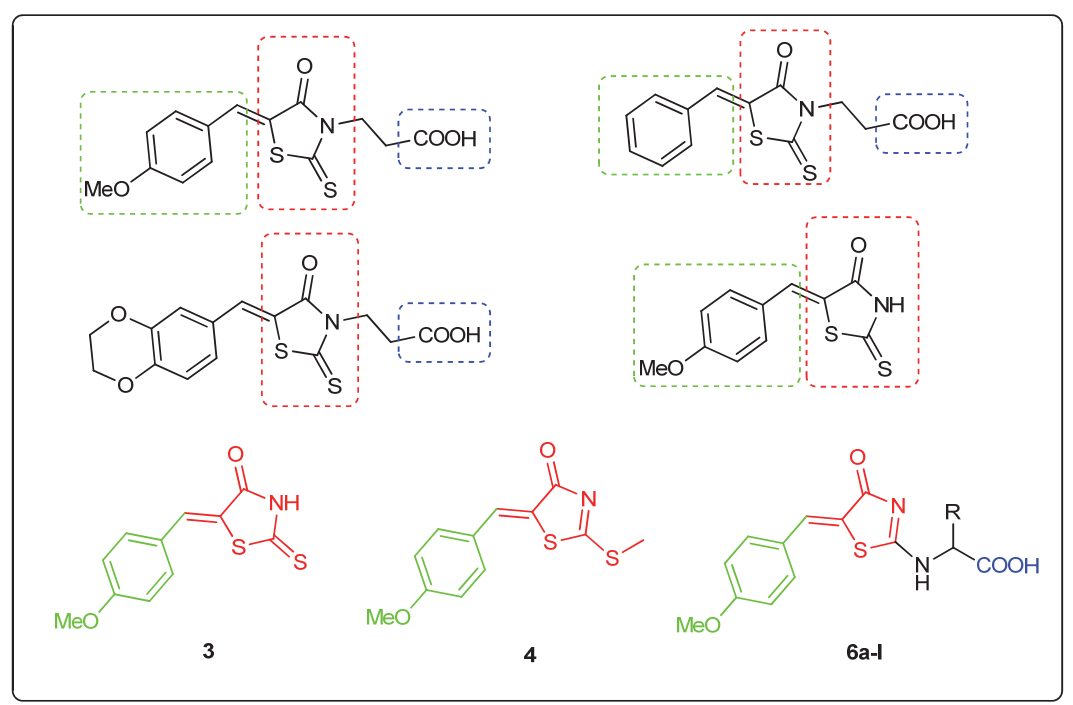

Fig. 1. Previously reported antimicrobial agents and synthesized compounds.

The most common protocol for the synthesis of thioxothiazolidinone involves active methylene group followed by intermolecular condensation with aromatic substituted aldehyde. However, these reactions required long reactions times, high temperatures, produce by-products, expensive reagents and, in general, have difficult purifications. ${ }^{23-25}$ Ultrasound irradiation, an efficient and innocuous technique for reagent activation in the synthesis of organic compounds, and in particular heterocyclic compounds, has been applied with success, and generates products in good to excellent yields. ${ }^{26-28}$ Ultrasound-promoted synthesis has attracted much attention during the past few decades. One advantage of using cavitation as an energy source to promote organic reactions includes shorter reaction times. Compared with conventional synthetic methods, the ultrasound- assisted method is reported as a fast, simple, convenient, time saving, economical, and environmentally benign method for the synthesis of novel materials. ${ }^{29-31}$ It was known that the ultrasound agitation generate notable effects of chemical and physical effects due to the acoustic cavitation. ${ }^{32,33}$ Ultrasonic irradiation has been acknowledged as an innocuous, green technique and its application today has been a boon in serving a new pathway for several chemical processes like reagent activation in the synthesis of organic and inorganic compounds. ${ }^{34}$

In view of the above considerations and in continuation of our previous work on thiazoles, thiazolidinones and sulphonamide derivatives of pharmaceutical interest, ${ }^{35-47}$ we wish to report a simple, mild, competent and environmentally benign method for the synthesis and characterization of novel rhodanine derivatives $\mathbf{3}, \mathbf{4}$ and $\mathbf{6 a - 1}$ by ultrasound irradiation and conventional technique via potassium carbonate catalyzed in water media.

\section{Results and discussion}

The synthetic protocols employed for the synthesis of rhodanine derivatives $\mathbf{3}$ and $\mathbf{4}$ presented in scheme 1, scheme 2 and 6a-I are presented in scheme 3. The compound (Z)-5-(4methoxybenzylidene)-2-thioxothiazolidin-4-one $\mathbf{3}$ was prepared via a Knoevenagel condensation between and 4-methoxybenzaldehyde (1) with rhodanine (2). The compound (Z)-5-(4methoxybenzylidene)-2-(methylthio)thiazol-4(5H)-one 4 was obtained via reaction of the compound (3) with iodomethane in water using triethylamine as base. 
Table 1. Ultrasound irradiation: Screening of base, solvents, reaction time and yield for the synthesis $(\mathbf{6 a})^{\mathrm{a}}$

\begin{tabular}{ccccc}
\hline Entry & Base & Solvent & Time (min) & Yield $\mathbf{~ ( \% ) ~}$ \\
\hline 1 & Diethylamine & Water & 12 & 62 \\
2 & Diethylamine & Methanol & 18 & 32 \\
3 & Diethylamine & Acetic acid & 15 & 32 \\
4 & Diethylamine & DCM & 16 & 43 \\
5 & Diethylamine & Toluene & 14 & 34 \\
6 & Triethylamine & Water & 8 & 72 \\
7 & Triethylamine & Methanol & 13 & 42 \\
8 & Triethylamine & Acetic acid & 14 & 33 \\
9 & Triethylamine & DCM & 12 & 44 \\
10 & Triethylamine & Toluene & 18 & 36 \\
11 & Potassium carbonate & Water & 1 & 99 \\
12 & Potassium carbonate & Methanol & 12 & 72 \\
13 & Potassium carbonate & Acetic acid & 10 & 73 \\
14 & Potassium carbonate & DCM & 8 & 72 \\
15 & Potassium carbonate & Toluene & 10 & 66 \\
\hline
\end{tabular}

${ }^{a}$ All the reaction was carried out in equimolar amounts of each compound in $1 \mathrm{~mL}$ of solvent ${ }^{\mathrm{b}}$ Isolated yield.

\subsection{Effect of base and solvents}

A variety of bases were screened under ultrasound irradiation in order to validate the right choice and the results are shown in Table 1 . To justify the influence of the base, the reaction was carried out in the presence of base potassium carbonate wherein a maximum yield of $99 \%$ could be obtained (Table 1, Entry 11). It was further observed that the yield of the reaction hardly improved in the presence of other like diethylamine and triethylamine bases (Table 1, Entries 1 and 6), whereas the use of potassium carbonate as base significantly improved the yield to 99\% (Table 1, Entry 11). Hence potassium carbonate under ultrasonic irradiation was selected for our further studies.

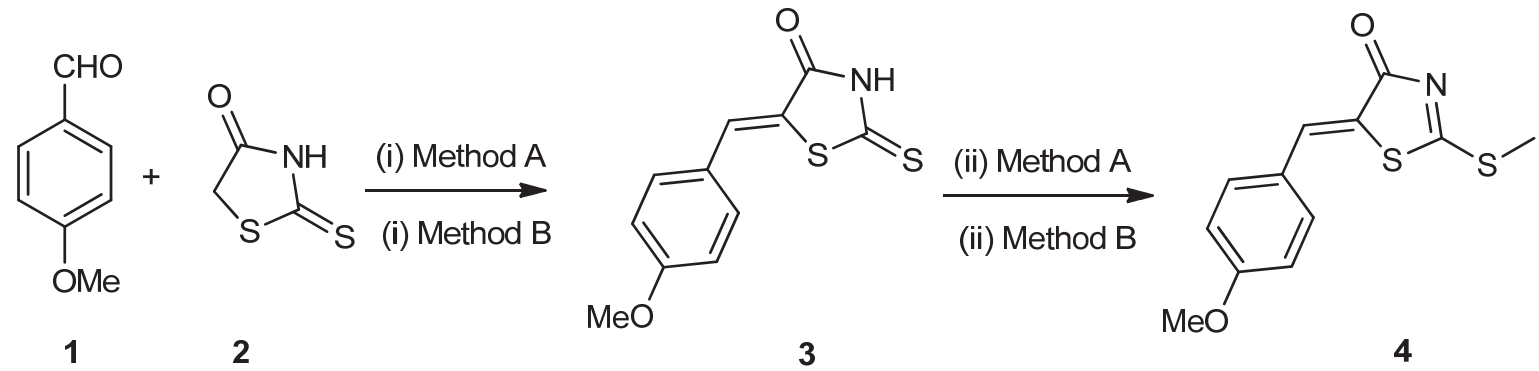

aReaction condition: (i) Method A: Ultrasound irradiation: Sodium acetate, Acetic acid, $25^{\circ} \mathrm{C}, 25$ min. (i) Method B: Conventional method: Sodium acetate, Acetic acid, reflux, 2 h. (ii) Method A: Ultrasound irradiation: Triethylamine, Iodomethane, Water, rt, 3 min. (ii) Method B: Conventional method: Triethylamine, Iodomethane, Water, rt, $1 \mathrm{~h}$.

Scheme 1. Synthesis of (Z)-5-(4-methoxybenzylidene)-2-(methylthio)thiazol-4(5H)-one (4) ${ }^{\mathrm{a}}$ 

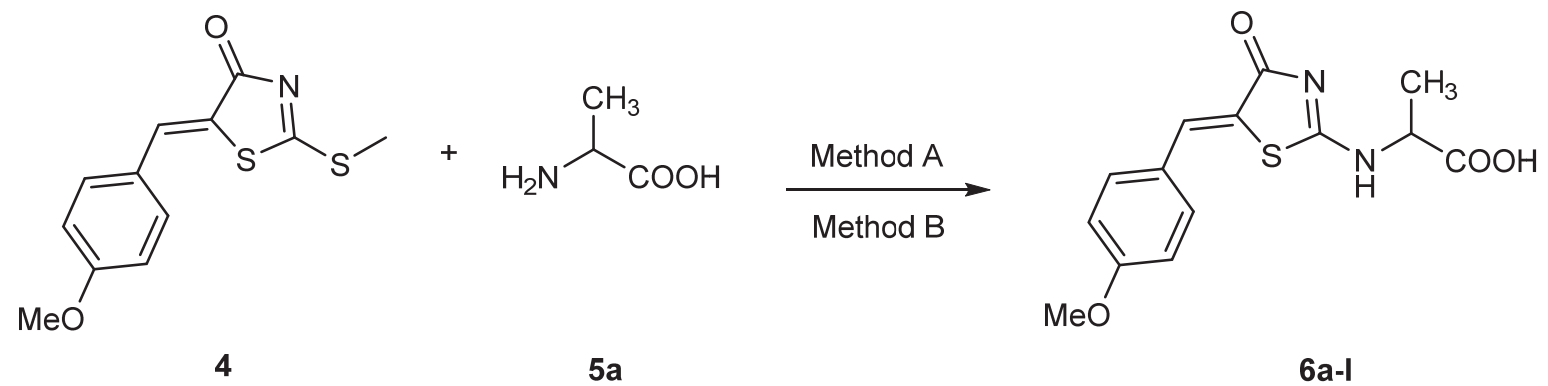

6a-I

aReaction condition: Method A: Ultrasound irradiation: Compound 4 (1 mmol), L-Alanine (5a) (1.2 $\mathrm{mmol})$, base (1 mmol), solvent $1 \mathrm{~mL}$, rt. 1-18 min. Method B: Conventional method: Compound 4 (1 mmol), L-Alanine (5a) $(1.2 \mathrm{mmol})$, base (1 mmol), solvent $1 \mathrm{~mL}, \mathrm{rt.}$ 10-98 min.

Scheme 2. Screening of model reaction (Z)-2-((5-(4-methoxybenzylidene)-4-oxo-4,5-dihydrothiazol2-yl)amino)propanoic acid (6a) ${ }^{\mathrm{a}}$

We synthesized and screening of model reaction under ultrasound irradiation and conventional method of the compound (Z)-2-((5-(4-methoxybenzylidene)-4-oxo-4,5-dihydrothiazol-2-yl)amino) propanoic acid 6a (Scheme 2, Table 1, Table 2). The reaction in which the compound 4 (1 mmol) and the compound $\mathbf{5 a}(1.2 \mathrm{mmol})$, various base and various solvents were selected as a model reaction to optimize the reaction conditions. In terms of the effect of solvents and base on the condensation reaction, potassium carbonate was found to be the better base and water was found to be the best solvent for the reaction (Table 1, entry 11); other solvents, including methanol, acetic acid, dichloromethane (DCM) and toluene were less efficient (Table 1, entries 2-5, 7-10 and 12-15).

Table 2. Conventional method: Screening of base, solvents, reaction time and yield for the synthesis $(\mathbf{6 a})^{\mathrm{a}}$

\begin{tabular}{|c|c|c|c|c|}
\hline Entry & Base & Solvent & Time (min) & Yield $^{\mathrm{b}}(\%)$ \\
\hline 1 & Diethylamine & Water & 80 & 58 \\
\hline 2 & Diethylamine & Methanol & 90 & 30 \\
\hline 3 & Diethylamine & Acetic acid & 95 & 35 \\
\hline 4 & Diethylamine & DCM & 98 & 40 \\
\hline 5 & Diethylamine & Toluene & 92 & 30 \\
\hline 6 & Triethylamine & Water & 82 & 68 \\
\hline 7 & Triethylamine & Methanol & 84 & 40 \\
\hline 8 & Triethylamine & Acetic acid & 86 & 30 \\
\hline 9 & Triethylamine & DCM & 84 & 45 \\
\hline 10 & Triethylamine & Toluene & 88 & 35 \\
\hline 11 & Potassium carbonate & Water & 10 & 88 \\
\hline 12 & Potassium carbonate & Methanol & 40 & 79 \\
\hline 13 & Potassium carbonate & Acetic acid & 44 & 76 \\
\hline 14 & Potassium carbonate & DCM & 46 & 78 \\
\hline 15 & Potassium carbonate & Toluene & 48 & 68 \\
\hline
\end{tabular}

Water gave the corresponding product in $62-99 \%$ yield, which was the best among these solvents (Table 1, entries 1, 6 and 11). To increase the efficiency of the condensation reaction, the effects of different base were investigated (Table 1, entries 1-15). Potassium carbonate exhibited the best performance with used solvents and gave better yield, (Table 1, entries 11-15). Sodium acetate and triethylamine gave lower yields with other solvents, but gave better yield in water as a solvent (Table 1 , entries 1 and 6). All the reactions were carried out in equimolar amounts of each compound in $1 \mathrm{~mL}$ 
of solvent. Among these reactions same amounts of the solvent, namely $1 \mathrm{~mL}$ of water turned out to be the best choice with yields of $62 \%, 72 \%$ and $99 \%$ (Table 1, entries 1, 6 and 11).

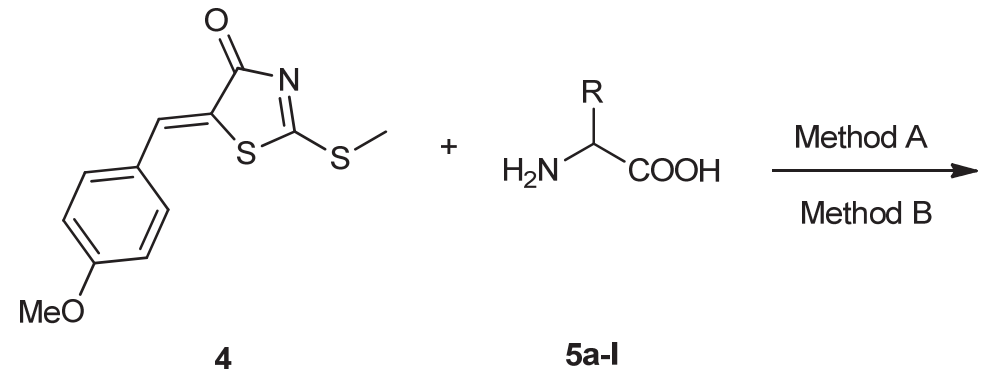

4

$$
\begin{array}{rlrl}
R=5 a & =6 a=-C_{3} & 5 e=6 e=-\mathrm{CH}_{2} \mathrm{CH}_{2} \mathrm{SCH}_{3} \\
5 b=6 b=-\mathrm{CH}\left(\mathrm{CH}_{3}\right)_{2} & 5 f=6 f=-\mathrm{CH}_{2} \mathrm{CH}\left(\mathrm{CH}_{3}\right)_{2} \\
5 c=6 c=-\mathrm{CH}\left(\mathrm{CH}_{3}\right) \mathrm{CH}_{2} \mathrm{CH}_{3} & 5 \mathrm{~g}=6 \mathrm{~g}=-\mathrm{CH}_{2} \mathrm{OH} \\
5 \mathrm{~d}=6 \mathrm{~d}=-\mathrm{CH}_{2} \mathrm{C}_{6} \mathrm{H}_{5} & 5 \mathrm{~h}=6 \mathrm{~h}=-\mathrm{CH}_{2} \mathrm{SH}
\end{array}
$$<smiles>[R]C(NC1=NC(=O)/C(=C/c2ccc(OC)cc2)S1)C(=O)O</smiles>

$6 a-I$$$
\begin{aligned}
& 5 i=6 i=-\mathrm{CH}_{2} \mathrm{COOH} \\
& 5 \mathrm{j}=6 \mathrm{j}=- \\
& 5 \mathrm{k}=6 \mathrm{k}=-\mathrm{CH}_{2} \mathrm{C}_{6} \mathrm{H}_{4} \mathrm{OH} \\
& 5 \mathrm{l}=6 \mathrm{l}=-\mathrm{CHOHCH}_{3}
\end{aligned}
$$

${ }^{a}$ Reaction condition: Method A: Ultrasound irradiation: potassium carbonate, water, rt, 1-4 min. Method B: Conventional: potassium carbonate, water, rt, 10-30 min.

Scheme 3. Synthesis of (Z)-2-((5-(4-methoxybenzylidene)-4-oxo-4,5-dihydrothiazol-2-yl)amino) substituted acid (6a-l). ${ }^{\text {a }}$

We also synthesized and screening of model reaction under conventional method and the results of these findings are presented in Table 2. The reaction in which the compound $4(1 \mathrm{mmol})$ and the compound $\mathbf{5 a}(1.2 \mathrm{mmol})$, various base and various solvents were selected as a model reaction to optimize the reaction conditions. In terms of the effect of solvents and base on the condensation reaction, potassium carbonate was found to be the better base and water was found to be the best solvent for the reaction (Table 2, entry 11); other solvents, including methanol, acetic acid, DCM and toluene were less efficient (Table 2, entries 2-5, 7-10 and 12-15). Nevertheless, all of these yields were

\begin{tabular}{|c|c|c|c|c|c|c|}
\hline \multirow[t]{2}{*}{ Sr. No. } & \multirow[t]{2}{*}{ Substituent (R) } & \multicolumn{2}{|c|}{ Time (min) } & \multicolumn{2}{|c|}{ Yield $^{\mathrm{b}}(\%)$} & \multirow{2}{*}{$\begin{array}{c}\text { Melting } \\
\text { point }\left({ }^{\circ} \mathbf{C}\right)\end{array}$} \\
\hline & & $\begin{array}{l}\text { Ultrasound } \\
\text { irradiation }\end{array}$ & $\begin{array}{c}\text { Conventional } \\
\text { method }\end{array}$ & $\begin{array}{l}\text { Ultrasound } \\
\text { irradiation }\end{array}$ & $\begin{array}{c}\text { Conventional } \\
\text { method }\end{array}$ & \\
\hline 6a & $-\mathrm{CH}_{3}$ & 1 & 10 & 99 & 88 & $220-222$ \\
\hline $6 \mathbf{b}$ & $-\mathrm{CH}\left(\mathrm{CH}_{3}\right)_{2}$ & 1 & 30 & 98 & 85 & $212-214$ \\
\hline $6 c$ & $-\mathrm{CH}\left(\mathrm{CH}_{3}\right) \mathrm{CH}_{2} \mathrm{CH}_{3}$ & 2 & 25 & 98 & 88 & $148-150$ \\
\hline 6d & $-\mathrm{CH}_{2} \mathrm{C}_{6} \mathrm{H}_{5}$ & 2 & 25 & 97 & 88 & $178-180$ \\
\hline $6 e$ & $-\mathrm{CH}_{2} \mathrm{CH}_{2} \mathrm{SCH}_{3}$ & 3 & 25 & 98 & 92 & $176-178$ \\
\hline $6 f$ & $-\mathrm{CH}_{2} \mathrm{CH}\left(\mathrm{CH}_{3}\right)_{2}$ & 3 & 30 & 98 & 90 & $238-240$ \\
\hline $6 \mathrm{~g}$ & $-\mathrm{CH}_{2} \mathrm{OH}$ & 4 & 25 & 97 & 88 & $241-243$ \\
\hline $6 \mathrm{~h}$ & $-\mathrm{CH}_{2} \mathrm{SH}$ & 4 & 28 & 96 & 90 & $256-258$ \\
\hline $6 \mathbf{i}$ & $-\mathrm{CH}_{2} \mathrm{COOH}$ & 4 & 25 & 97 & 90 & $173-175$ \\
\hline $6 \mathbf{j}$ & $\mathrm{N}$ & 2 & 30 & 98 & 90 & $198-200$ \\
\hline $6 \mathbf{k}$ & $-\mathrm{CH}_{2} \mathrm{C}_{6} \mathrm{H}_{4} \mathrm{OH}$ & 2 & 25 & 98 & 88 & $157-159$ \\
\hline 61 & $-\mathrm{CHOHCH}_{3}$ & 3 & 22 & 98 & 82 & $181-183$ \\
\hline \multicolumn{7}{|c|}{$\begin{array}{l}\text { 'Reaction condition (6a-l). Compound (4) (1 mmol), amino acids (5a-l) }(1.2 \mathrm{mmol}) \text {, } \\
\text { Method A: Ultrasound irradiation: potassium carbonate, Water, rt, 1-4 min. } \\
\text { Method B: Conventional method: potassium carbonate, Water, rt, 10-30 min. } \\
\text { 'Isolated yields }\end{array}$} \\
\hline
\end{tabular}
generally low before further optimizations. Water gave the corresponding product in $58-88 \%$ yield, which was the best among these solvents (Table 2, entries 1, 6 and 11).

Table 3. Physical data for synthesized rhodanine derivatives $\mathbf{6}(\mathbf{a}-\mathbf{l})^{\mathrm{a}}$ 
To increase the efficiency of the condensation reaction, the effects of different base were investigated (Table 2, entries 1-15). Potassium carbonate exhibited the best performance with used solvents and gave better yield, (Table 2, entries 11-15). Sodium acetate and triethylamine gave lower yields with other solvents, but gave better yield in ethanol as a solvent (Table 2, entries 1 and 6). All the reactions were carried out in equimolar amounts of each compound in $1 \mathrm{~mL}$ of solvent. Among these reactions same amounts of the solvent, namely $1 \mathrm{~mL}$ of ethanol turned out to be the best choice with yields of 58\%, 68\% and 88\% (Table 2, entries 1, 6 and 11).

We would like to mention here that water as a solvent with potassium carbonate as base was the best choice with a yield of $99 \%$ and less time required for the completion of the reaction (Table 1, entry 11). Thus we decided to carry out the further reactions in water as a solvent with potassium carbonate as a base. As a result the reaction time was shortened; thermal decomposition was also minimized, at room temperature stirring, resulting in higher isolated yields. But in this synthesis, we compared to the reaction between ultrasound irradiation and conventional method, the ultrasound irradiation is the best method. Because the studies indicated that the use of ultrasound irradiation made the reactions very fast, very less time required to complete the reaction, and recorded high product yields $62 \%, 72 \%$ and 99\% (Table 1, entries 1, 6 and 11) and surprisingly, in the conventional method, the reactions very sluggish and recorded low yields 58\%, 68\% and 88\% (Table 2, entries 1, 6 and 11).

The physical data of the synthesized compounds are presented in Table 3. All the reactions proceeded well in 1-4 min to give products in very good yields (96-99\%) by ultrasound irradiation and in conventional method, the reactions proceeded in 10-30 min to give products in yields (82-90\%). The purity of the synthesized compounds was checked by TLC on silica gel precoated F254 Merck plates and melting points were recorded on SRS Optimelt, melting point apparatus and are uncorrected. The structure of the synthesized compounds was confirmed by IR, ${ }^{1} \mathrm{H}$ NMR, ${ }^{13} \mathrm{C}$ NMR and Mass spectral analysis.

\section{Conclusions}

With the pervasive applicability and pharmacoactivity of these derivatives, we have herein devised an energy efficient, general, cost effective and eco sustainable method for the synthesis of a series of rhodanine derivatives 3,4 and 6a-l. The promising salient features of this strategy are absence of toxic organic solvents, minimization of waste, ease of product isolation, rapid, avoids laborious column purification steps, economically viable, easy to operate, rate and yield enhancements. The present method will permit a further increase of the diversity within rhodanine derivatives. It is envisaged that, the utility of sonication in combination with water as solvent and potassium carbonate as a base will make further development and good prospects for industrial application, synthetic chemistry and chemical science.

\section{Acknowledgement}

The authors are thankful to the Head, Department of Chemical Technology, Dr. Babasaheb Ambedkar Marathwada University, Aurangabad 431004 (MS) India, for providing the laboratory facility. The authors would like to also thank the anonymous referees for constructive comments on earlier version of this paper.

\section{Experimental section}

\subsection{Material and methods}

Rhodanine, 4-methoxybenzaldehyde, anhydrous sodium acetate, triethylamine, dichloromethane, iodomethane and various solvents were commercially available. The major chemicals were purchased 
from Sigma Aldrich and Avra labs. Reaction courses were monitored by TLC on silica gel precoated F254 Merck plates. Developed plates were examined with UV lamps (254 nm). IR spectra were recorded on a FT-IR (Bruker). Melting points were recorded on SRS Optimelt, melting point apparatus and are uncorrected. The Ultrasonic Bath, sonicator of PCI Analytics having ultrasound cleaner with a frequency of $35 \mathrm{kHz}$ and constant frequency $100 \mathrm{~W}$ maintained at $25^{\circ} \mathrm{C}$ by circulating water. ${ }^{1} \mathrm{H}$ NMR spectra were recorded on a $400 \mathrm{MHz}$ Varian NMR spectrometer and DMSO solvent is used. The following abbreviations are used; singlet (s), doublet (d), triplet (t), quartet (q), multiplet (m) and broad (br). Mass spectra were taken with Micromass-QUATTRO-II of WATER mass spectrometer.

\subsection{General procedure for the synthesis of compounds (3)}

\subsubsection{Method A: Ultrasound irradiation}

A $50 \mathrm{~mL}$ flask was charged with 4-methoxybenzaldehyde 1 (1 mmol), 2-thioxothiazolidin-4-one 2 $(1 \mathrm{mmol})$, anhydrous sodium acetate $(1 \mathrm{mmol})$, acetic acid $(1 \mathrm{~mL})$. The mixture was sonicated $(35 \mathrm{kHz}$, constant frequency) at $25^{\circ} \mathrm{C}$ for $25 \mathrm{~min}$. The progress of the reaction was monitored by TLC (20\% ethyl acetate: $n$-hexane). After completion of the reaction, the reaction mixture was poured into the icecold water. The precipitate was filtered off and washed with water $(3 \times 10 \mathrm{~mL})$, dried and purified by recrystallized in ethanol as solvent to give $98 \%$ yield.

\subsubsection{Method B: Conventional method}

A $50 \mathrm{~mL}$ round bottom flask, an equimolar amount of 4-methoxybenzaldehyde 1 (1 mmol), 2thioxothiazolidin-4-one 2 ( $1 \mathrm{mmol})$, anhydrous sodium acetate $(1 \mathrm{mmol})$ and acetic acid $(1 \mathrm{~mL})$ were added. The mixture was stirred under reflux condition for $2 \mathrm{~h}$. The progress of the reaction was monitored by TLC ( $20 \%$ ethyl acetate: $n$-hexane). After completion of the reaction, the reaction mixture was poured into the ice-cold water. The precipitate was filtered off and washed with water $(3 \times 10 \mathrm{~mL})$, dried and purified by recrystallized in ethanol as solvent to give $82 \%$ yield.

\subsubsection{1. (Z)-5-(4-methoxybenzylidene)-2-thioxothiazolidin-4-one (3)}

Yellow solid, Yield: $95 \%$. mp $247-249{ }^{\circ} \mathrm{C}$; ES-MS m/z: 251.32. IR vmax/cm ${ }^{-1}: 3082(\mathrm{NH}), 1729$ $(\mathrm{C}=\mathrm{O}), 1575(\mathrm{C}=\mathrm{C}), 1442(\mathrm{C}=\mathrm{N}), 1277(\mathrm{C}=\mathrm{S}), 1194(\mathrm{C}-\mathrm{N}) .{ }^{1} \mathrm{H}$ NMR $(400 \mathrm{MHz}, \mathrm{DMSO}-\mathrm{d} 6, \mathrm{ppm})=$ $3.90\left(\mathrm{~s}, 3 \mathrm{H}, \mathrm{OCH}_{3}\right), 6.60-6.62(\mathrm{~d}, J=7.2 \mathrm{~Hz}, 2 \mathrm{H}, \mathrm{Ar}-\mathrm{CH}), 7.30-7.32(\mathrm{~d}, J=7.2 \mathrm{~Hz}, 2 \mathrm{H}, \mathrm{Ar}-\mathrm{CH}), 7.70$ $(\mathrm{s}, 1 \mathrm{H},=\mathrm{CH}), 13.70(\mathrm{~s}, 1 \mathrm{H}, \mathrm{NH}) .{ }^{13} \mathrm{C} \mathrm{NMR}: \delta \mathrm{ppm}=55.8,114.3,116.0,130.7,142.9,143.4,160.5$, 168.4, 193.7.

\subsubsection{General procedure for the synthesis of compounds (4)}

\subsubsection{Method A: Ultrasound irradiation}

A $50 \mathrm{~mL}$ flask was charged with, the compound (Z)-5-(4-methoxybenzylidene)-2-thioxothiazolidin4-one 3 (1 mmol), triethylamine $(1.2 \mathrm{mmol})$, iodomethane $(1.2 \mathrm{mmol})$ and water $(1 \mathrm{~mL})$. The mixture was sonicated $\left(35 \mathrm{kHz}\right.$, constant frequency) at $25^{\circ} \mathrm{C}$ for $3 \mathrm{~min}$. The progress of the reaction was monitored by TLC ( $10 \%$ methanol: chloroform). After completion of the reaction, the reaction mixture was concentrated in-vacuo. The residue was washed with water $(3 \times 15 \mathrm{~mL})$ to afford the crude product. The crude product was recrystallized using ethanol as solvent to give yield in the range $95 \%$.

\subsubsection{Method B: Conventional method}

In a $50 \mathrm{ml}$ round bottom flask, the compound (Z)-5-(4-methoxybenzylidene)-2-thioxothiazolidin4-one 3 (1 mmol), triethylamine $(1.2 \mathrm{mmol})$, iodomethane $(1.2 \mathrm{mmol})$, water $(1 \mathrm{~mL})$ stirred at room 
temperature up to $2 \mathrm{~h}$. The progress of the reaction was monitored by TLC ( $10 \%$ methanol: chloroform). After completion of the reaction, the reaction mixture was concentrated in-vacuo. The residue was washed with water $(3 \times 15 \mathrm{~mL})$ to afford the crude product. The crude product was recrystallized using ethanol as solvent to give yield in the range $85 \%$.

\subsubsection{1. (Z)-5-(4-methoxybenzylidene)-2-(methylthio)thiazol-4(5H)-one (4)}

Yellow solid, Yield: $95 \%$. mp $162-164{ }^{\circ} \mathrm{C}$; ES-MS m/z: 265.35. IR vmax $/ \mathrm{cm}^{-1}: 1681(\mathrm{C}=\mathrm{O}), 1572$ $(\mathrm{C}=\mathrm{C}), 1503(\mathrm{C}=\mathrm{N}), 1149(\mathrm{C}-\mathrm{S}), 911(\mathrm{C}-\mathrm{N}) .{ }^{1} \mathrm{H}$ NMR $(400 \mathrm{MHz}, \mathrm{DMSO}-\mathrm{d} 6, \mathrm{ppm})=2.80$ (s, 3H, S$\left.\mathrm{CH}_{3}\right), 3.80\left(\mathrm{~s}, 3 \mathrm{H}, \mathrm{OCH}_{3}\right), 6.70-6.72(\mathrm{~d}, 2 \mathrm{H}, \mathrm{Ar}-\mathrm{CH}), 7.30-7.32(\mathrm{~d}, 2 \mathrm{H}, \mathrm{Ar}-\mathrm{CH}), 7.90(\mathrm{~s}, 1 \mathrm{H},=\mathrm{CH})$. ${ }^{13} \mathrm{C}$ NMR: $\delta \mathrm{ppm}=14.4,55.8,114.2,127.5,130.5,132.6,152.3,160.1,162.7,167.2$.

\subsection{General procedure for the synthesis of (Z)-2-((5-(4-methoxybenzylidene)-4-oxo-4,5- dihydrothiazol-2-yl)amino)substituted acid (6a-l)}

\subsubsection{Method A: Ultrasound irradiation:}

A $50 \mathrm{~mL}$ flask was charged with, the compound (Z)-5-(4-methoxybenzylidene)-2(methylthio)thiazol-4(5H)-one 4 (1 mmol), amino acids 5a-l $(1.2 \mathrm{mmol})$, potassium carbonate $(1 \mathrm{mmol})$ and water $(1 \mathrm{~mL})$. The mixture was sonicated $\left(35 \mathrm{kHz}\right.$, constant frequency) at $25{ }^{\circ} \mathrm{C}$ for $1-4 \mathrm{~min}$. The progress of the reaction was monitored by TLC (10\% methanol: chloroform). After completion of the reaction, the reaction mixture was concentrated in-vacuo. The residue was washed with water $(3 \times 15$ $\mathrm{mL})$ to afford the crude product. The compounds (Z)-2-((5-(4-methoxybenzylidene)-4-oxo-4,5dihydrothiazol-2-yl)amino) substituted acid 6a-l were recrystallized from ethanol and isolated as yellowish solids.

\subsubsection{Method B: Conventional method:}

In a $50 \mathrm{ml}$ round bottom flask, the compound (Z)-5-(4-methoxybenzylidene)-2-(methylthio)thiazol$4(5 \mathrm{H})$-one $4(1 \mathrm{mmol})$, amino acids $5 \mathrm{a}-\mathrm{l}(1.2 \mathrm{mmol})$, potassium carbonate $(1 \mathrm{mmol})$ and water $(1 \mathrm{~mL})$ were added to the reaction mixter and stirred for 10-30 min at room temperature. The progress of the reaction was monitored by TLC (10\% methanol: chloroform). After completion of the reaction, the reaction mixture was concentrated in-vacuo. The residue was washed with water $(3 \times 15 \mathrm{~mL})$ to afford the crude product. The compounds (Z)-2-((5-(4-methoxybenzylidene)-4-oxo-4,5-dihydrothiazol-2yl)amino) substituted acid 6a-l were recrystallized from ethanol and isolated as yellowish solids.

\subsubsection{1. (Z)-2-((5-(4-methoxybenzylidene)-4-oxo-4,5-dihydrothiazol-2-yl)amino)propanoic acid (6a)}

Yellow solid, Yield: $99 \%$, mp 220-222 ${ }^{\circ} \mathrm{C}$; ES-MS m/z: 306.34. IR vmax $/ \mathrm{cm}^{-1}: 3384(\mathrm{OH}), 2657(\mathrm{CH}-$ Ar), $1737(\mathrm{HO}-\mathrm{C}=\mathrm{O}), 1690(\mathrm{C}=\mathrm{O}), 1599(\mathrm{C}=\mathrm{C}), 1553(\mathrm{C}=\mathrm{N}), 1006(\mathrm{C}-\mathrm{S}), 761(\mathrm{C}-\mathrm{N}) .{ }^{1} \mathrm{H}$ NMR $(400$ MHz, DMSO-d6, ppm) = 1.30-1.32 (d, 3H, $\left.\mathrm{CH}_{3}\right), 3.80\left(\mathrm{~s}, 3 \mathrm{H}, \mathrm{OCH}_{3}\right), 4.50-4.52(\mathrm{q}, 1 \mathrm{H}, \mathrm{CH}), 7.50-$ $7.70(\mathrm{~m}, 4 \mathrm{H}, \mathrm{Ar}-\mathrm{CH}), 7.80(\mathrm{~s}, 1 \mathrm{H},=\mathrm{CH}), 8.40(\mathrm{~s}, 1 \mathrm{H}, \mathrm{NH}), 10.15(\mathrm{~s}, 1 \mathrm{H}, \mathrm{COOH}) .{ }^{13} \mathrm{C} \mathrm{NMR}: \delta \mathrm{ppm}=$ $16.8,53.5,55.5,56.2,114.1,130.4,132.5,143.4,152.3,158.6,160.7,167.7,174.2$.

\subsubsection{2. (Z)-2-((5-(4-methoxybenzylidene)-4-oxo-4,5-dihydrothiazol-2-yl)amino)-3-methyl butanoic acid (6b)}

Yellow solid, Yield: 98\%, mp 212-214 ${ }^{\circ} \mathrm{C}$; ES-MS m/z: 334.39. IR vmax $/ \mathrm{cm}^{-1}: 3744(\mathrm{OH}), 3011$ $(\mathrm{NH}), 1737(\mathrm{HO}-\mathrm{C}=\mathrm{O}), 1689(\mathrm{C}=\mathrm{O}), 1553(\mathrm{C}=\mathrm{C}), 1509(\mathrm{C}=\mathrm{N}), 1232(\mathrm{C}-\mathrm{S}), 1010(\mathrm{C}-\mathrm{N}) .{ }^{1} \mathrm{H}$ NMR $(400 \mathrm{MHz}, \mathrm{DMSO}-\mathrm{d} 6, \mathrm{ppm})=0.90-0.92\left(\mathrm{~d}, 6 \mathrm{H}, \mathrm{CH}_{3}\right), 2.20-2.22(\mathrm{~m}, 1 \mathrm{H}, \mathrm{CH}), 3.80\left(\mathrm{~s}, 3 \mathrm{H}, \mathrm{OCH}_{3}\right)$, $4.50-4.52(\mathrm{~d}, 1 \mathrm{H}, \mathrm{CH}), 7.40-7.42(\mathrm{~d}, J=7.2 \mathrm{~Hz}, 2 \mathrm{H}, \mathrm{Ar}-\mathrm{CH}), 7.60-7.62(\mathrm{~d}, J=7.2 \mathrm{~Hz}, 2 \mathrm{H}, \mathrm{Ar}-\mathrm{CH})$, 
$7.80(\mathrm{~s}, 1 \mathrm{H},=\mathrm{CH}), 10.02(\mathrm{~s}, 1 \mathrm{H}, \mathrm{NH}), 13.15(\mathrm{~s}, 1 \mathrm{H}, \mathrm{COOH}) .{ }^{13} \mathrm{C} \mathrm{NMR}: \delta \mathrm{ppm}=18.2,30.1,55.6,61.3$, 114.3, 127.6, 130.7, 132.4, 153.3, 157.6, 161.7, 168.7, 174.4 .

\subsubsection{3. (Z)-2-((5-(4-methoxybenzylidene)-4-oxo-4,5-dihydrothiazol-2-yl)amino)-3-methyl pentanoic} acid (6c)

Yellow solid, Yield: $98 \%$, mp $148-150^{\circ} \mathrm{C}$; ES-MS m/z: 348.42. IR vmax/ $\mathrm{cm}^{-1}: 3624$ (OH), 3563 (NH), 2969 (Ar-CH), $1730(\mathrm{HO}-\mathrm{C}=\mathrm{O}), 1641(\mathrm{C}=\mathrm{O}), 1609(\mathrm{C}=\mathrm{C}), 1584(\mathrm{C}=\mathrm{N}), 1183(\mathrm{C}-\mathrm{S}), 1093(\mathrm{C}-\mathrm{N}) .{ }^{1} \mathrm{H}$ NMR (400 MHz, DMSO-d6, ppm) $=1.10-1.12\left(\mathrm{~m}, 8 \mathrm{H}, \mathrm{CH}_{2} \mathrm{CH}_{3}\right), 1.30-1.32(\mathrm{~m}, 1 \mathrm{H}, \mathrm{CH}), 3.20-3.22$ $(\mathrm{d}, 1 \mathrm{H}, \mathrm{CH}), 3.70\left(\mathrm{~s}, 3 \mathrm{H}, \mathrm{OCH}_{3}\right), 7.40-7.42(\mathrm{~d}, J=7.6 \mathrm{~Hz}, 2 \mathrm{H}, \mathrm{Ar}-\mathrm{CH}), 7.90(\mathrm{~s}, 1 \mathrm{H},=\mathrm{CH}), 8.20(\mathrm{~d}, J$ $=7.6 \mathrm{~Hz}, 2 \mathrm{H}, \mathrm{Ar}-\mathrm{CH}), 8.80(\mathrm{~s}, 1 \mathrm{H}, \mathrm{NH}), 10.30(\mathrm{~s}, 1 \mathrm{H}, \mathrm{COOH}) .{ }^{13} \mathrm{C} \mathrm{NMR}: \delta \mathrm{ppm}=11.2,15.2,25.2$, $37.5,55.3,55.6,56.2,55.8,130.6,132.7,143.4,152.3,161.7,167.7,174.6$.

\subsubsection{4. (Z)-2-((5-(4-methoxybenzylidene)-4-oxo-4,5-dihydrothiazol-2-yl)amino)-3-phenyl propanoic acid (6d)}

Yellow solid, Yield: $97 \%$, mp $178-180{ }^{\circ} \mathrm{C}$; ES-MS m/z: 382.43. IR vmax $/ \mathrm{cm}^{-1}: 3392(\mathrm{OH}), 3210$ $(\mathrm{NH}), 2976(\mathrm{CH}-\mathrm{Ar}), 1730(\mathrm{HO}-\mathrm{C}=\mathrm{O}), 1699(\mathrm{C}=\mathrm{O}), 1563(\mathrm{C}=\mathrm{C}), 1544(\mathrm{C}=\mathrm{N}), 1012(\mathrm{C}-\mathrm{S}), 1068(\mathrm{C}-$ N). ${ }^{1} \mathrm{H}$ NMR (400 MHz, DMSO-d6, ppm) = 2.50-2.52 (d, 2H, $\left.\mathrm{CH}_{2}\right), 3.80\left(\mathrm{~s}, 3 \mathrm{H}, \mathrm{OCH}_{3}\right), 4.40-4.42$ (q, 1H, CH), 7.20-7.70 (m, 9H, Ar-CH), $7.90(\mathrm{~s}, 1 \mathrm{H},=\mathrm{CH}), 9.14(\mathrm{~s}, 1 \mathrm{H}, \mathrm{NH}), 11.02(\mathrm{~s}, 1 \mathrm{H}, \mathrm{COOH})$. ${ }^{13} \mathrm{C}$ NMR: $\delta p p m=55.4,56.2,36.4,58.4,114.5,125.9,127.7,128.6,128.9,135.3,136.9,143.4,152.2$, $158.5,167.2,174.2$.

\subsubsection{5. (Z)-2-((5-(4-methoxybenzylidene)-4-oxo-4,5-dihydrothiazol-2-yl)amino)-4-(methylthio) butanoic acid (6e)}

Yellow solid, Yield: 98\%, mp 176-178 ${ }^{\circ} \mathrm{C}$; ES-MS m/z: 366.46. IR vmax $/ \mathrm{cm}^{-1}: 3475(\mathrm{OH}), 3213$ $(\mathrm{NH}), 2922(\mathrm{CH}-\mathrm{Ar}), 1719(\mathrm{HO}-\mathrm{C}=\mathrm{O}), 1699(\mathrm{C}=\mathrm{O}), 1582(\mathrm{C}=\mathrm{C}), 1452(\mathrm{C}=\mathrm{N}), 1215(\mathrm{C}-\mathrm{S}), 1029(\mathrm{C}-$ N). ${ }^{1} \mathrm{H}$ NMR $(400 \mathrm{MHz}, \mathrm{DMSO}-\mathrm{d} 6, \mathrm{ppm})=2.10\left(\mathrm{~s}, 3 \mathrm{H}, \mathrm{CH}_{3}\right), 2.30-2.32\left(\mathrm{q}, 2 \mathrm{H}, \mathrm{CH}_{2}\right), 2.60-2.62(\mathrm{t}$, $\left.2 \mathrm{H}, \mathrm{CH}_{2}\right), 3.30-3.32(\mathrm{q}, 1 \mathrm{H}, \mathrm{CH}), 3.80\left(\mathrm{~s}, 3 \mathrm{H}, \mathrm{OCH}_{3}\right), 7.10-7.12(\mathrm{~d}, J=7.2 \mathrm{~Hz}, 2 \mathrm{H}, \mathrm{Ar}-\mathrm{CH}), 7.50$ $7.52(\mathrm{~d}, J=7.2 \mathrm{~Hz}, 2 \mathrm{H}, \mathrm{Ar}-\mathrm{CH}), 7.80(\mathrm{~s}, 1 \mathrm{H},=\mathrm{CH}), 9.30(\mathrm{~s}, 1 \mathrm{H}, \mathrm{NH}), 10.20(\mathrm{~s}, 1 \mathrm{H}, \mathrm{COOH}) .{ }^{13} \mathrm{C}$ NMR: $\delta$ ppm $=15.2,29.2,30.5,55.4,56.6,56.8,114.6,130.4,132.3,143.5,152.3,161.7,167.7,174.6$.

4.3.2.6. (Z)-2-((5-(4-methoxybenzylidene)-4-oxo-4,5-dihydrothiazol-2-yl)amino)-4-methyl pentanoic acid (6f)

Yellow solid, Yield: $98 \%$, mp 238-240 ${ }^{\circ} \mathrm{C}$; ES-MS m/z: 348.44. IR vmax $/ \mathrm{cm}^{-1}: 3382(\mathrm{OH}), 3212$ $(\mathrm{NH}), 3020(\mathrm{CH}-\mathrm{Ar}), 1721(\mathrm{HO}-\mathrm{C}=\mathrm{O}), 1699(\mathrm{C}=\mathrm{O}), 1515(\mathrm{C}=\mathrm{C}), 1574(\mathrm{C}=\mathrm{N}), 1023(\mathrm{C}-\mathrm{S}), 1051(\mathrm{C}-$ $\mathrm{N}) .{ }^{1} \mathrm{H}$ NMR $(400 \mathrm{MHz}, \mathrm{DMSO}-\mathrm{d} 6, \mathrm{ppm})=0.92-0.94\left(\mathrm{~d}, 6 \mathrm{H}, \mathrm{CH}-\left(\mathrm{CH}_{3}\right)_{2}\right), 1.42-1.44(\mathrm{~m}, 1 \mathrm{H}, \mathrm{CH})$, 1.70-1.72(t, 2H, $\left.\mathrm{CH}_{2}\right), 3.82\left(\mathrm{~s}, 3 \mathrm{H}, \mathrm{OCH}_{3}\right), 4.40-4.42(\mathrm{q}, 1 \mathrm{H}, \mathrm{CH}), 7.20-7.22(\mathrm{~d}, J=7.2 \mathrm{~Hz}, 2 \mathrm{H}, \mathrm{Ar}-$ $\mathrm{CH}), 7.50-7.52(\mathrm{~d}, J=7.2 \mathrm{~Hz}, 2 \mathrm{H}, \mathrm{Ar}-\mathrm{CH}), 7.80(\mathrm{~s}, 1 \mathrm{H},=\mathrm{CH}), 9.20(\mathrm{~s}, 1 \mathrm{H}, \mathrm{NH}), 11.84(\mathrm{~s}, 1 \mathrm{H}, \mathrm{COOH})$. ${ }^{13} \mathrm{C}$ NMR: $\delta \mathrm{ppm}=22.8,24.5,40.1,55.2,55.8,114.2,127.2,130.1,132.4,152.2,158.1,160.1,167.1$, 174.2 .

\subsubsection{7. (Z)-2-((5-(4-methoxybenzylidene)-4-oxo-4,5-dihydrothiazol-2-yl)amino)-3-hydroxy propanoic acid $(6 \mathrm{~g})$}

Yellow solid, Yield: 97\%, mp 241-243 ${ }^{\circ} \mathrm{C}$; ES-MS m/z: 332.34. IR vmax $/ \mathrm{cm}^{-1}: 3420(\mathrm{OH}), 3211$ $(\mathrm{NH}), 3017(\mathrm{CH}-\mathrm{Ar}), 1730(\mathrm{HO}-\mathrm{C}=\mathrm{O}), 1698(\mathrm{C}=\mathrm{O}), 1543(\mathrm{C}=\mathrm{C}), 1521(\mathrm{C}=\mathrm{N}), 1029(\mathrm{C}-\mathrm{S}), 1097(\mathrm{C}-$ N). ${ }^{1} \mathrm{H}$ NMR (400 MHz, DMSO-d6, ppm) = $3.60(\mathrm{t}, 1 \mathrm{H}, \mathrm{CH}), 3.85\left(\mathrm{~s}, 3 \mathrm{H}, \mathrm{OCH}_{3}\right), 4.01-4.03(\mathrm{~d}, 2 \mathrm{H}$, $\left.\mathrm{CH}_{2}\right), 5.30(\mathrm{~s}, 1 \mathrm{H}, \mathrm{OH}), 7.10-7.12(\mathrm{~d}, 2 \mathrm{H}, \mathrm{Ar}-\mathrm{CH}), 7.30(\mathrm{~d}, 2 \mathrm{H}, \mathrm{Ar}-\mathrm{CH}), 7.78(\mathrm{~s}, 1 \mathrm{H},=\mathrm{CH}), 9.12$ (s, 
$1 \mathrm{H}, \mathrm{NH}), 10.86(\mathrm{~s}, 1 \mathrm{H}, \mathrm{COOH}) .{ }^{13} \mathrm{C} \mathrm{NMR}: \delta \mathrm{ppm}=55.5,59.2,62.3,114.8,127.1,132.9,135.1,151.9$, $158.1,159.6,167.9,171.2$.

\subsubsection{8. (Z)-2-((5-(4-methoxybenzylidene)-4-oxo-4,5-dihydrothiazol-2-yl)amino)-3-mercapto} propanoic acid $(6 h)$

Yellow solid, Yield: 96\%, mp 256-258 ${ }^{\circ} \mathrm{C}$; ES-MS m/z: 338.40. IR vmax $/ \mathrm{cm}^{-1}: 3415(\mathrm{OH}), 3211$ $(\mathrm{NH}), 3011(\mathrm{CH}-\mathrm{Ar}), 2510(\mathrm{SH}), 1735(\mathrm{HO}-\mathrm{C}=\mathrm{O}), 1698(\mathrm{C}=\mathrm{O}), 1559(\mathrm{C}=\mathrm{C}), 1501(\mathrm{C}=\mathrm{N}), 1011(\mathrm{C}-$ S), $1099(\mathrm{C}-\mathrm{N}) .{ }^{1} \mathrm{H}$ NMR $(400 \mathrm{MHz}, \mathrm{DMSO}-\mathrm{d} 6, \mathrm{ppm})=1.40(\mathrm{~s}, 1 \mathrm{H}, \mathrm{SH}), 3.10-3.12\left(\mathrm{~d}, 2 \mathrm{H}, \mathrm{CH}_{2}\right)$, $3.82\left(\mathrm{~s}, 3 \mathrm{H}, \mathrm{OCH}_{3}\right), 4.15-4.17(\mathrm{t}, 1 \mathrm{H}, \mathrm{CH}), 7.02-7.04(\mathrm{~d}, J=7.6 \mathrm{~Hz}, 2 \mathrm{H}, \mathrm{Ar}-\mathrm{CH}), 7.42-7.44(\mathrm{~d}, J=$ $7.6 \mathrm{~Hz}, 2 \mathrm{H}, \mathrm{Ar}-\mathrm{CH}), 7.78(\mathrm{~s}, 1 \mathrm{H},=\mathrm{CH}), 9.88(\mathrm{~s}, 1 \mathrm{H}, \mathrm{NH}), 11.54(\mathrm{~s}, 1 \mathrm{H}, \mathrm{COOH}) .{ }^{13} \mathrm{C} \mathrm{NMR:} \delta \mathrm{ppm}=$ $26.9,55.2,60.5,114.7,128.8,130.1,132.5,143.6,152.9,158.3,167.2,178.2$.

\subsubsection{9. (Z)-2-((5-(4-methoxybenzylidene)-4-oxo-4,5-dihydrothiazol-2-yl)amino)succinic acid (6i)}

Yellow solid, Yield: 97\%, mp 173-175 ${ }^{\circ} \mathrm{C}$; ES-MS m/z: 350.37. IR vmax $/ \mathrm{cm}^{-1}: 3426(\mathrm{OH}), 3210$ $(\mathrm{NH}), 3016(\mathrm{CH}-\mathrm{Ar}), 1732(\mathrm{HO}-\mathrm{C}=\mathrm{O}), 1705(\mathrm{C}=\mathrm{O}), 1532(\mathrm{C}=\mathrm{C}), 1511(\mathrm{C}=\mathrm{N}), 1014(\mathrm{C}-\mathrm{S}), 1040(\mathrm{C}-$ $\mathrm{N}) .{ }^{1} \mathrm{H}$ NMR $(400 \mathrm{MHz}, \mathrm{DMSO}-\mathrm{d} 6, \mathrm{ppm})=2.61-2.63\left(\mathrm{~d}, 2 \mathrm{H}, \mathrm{CH}_{2}\right), 3.71-3.73(\mathrm{t}, 1 \mathrm{H}, \mathrm{CH}), 3.90(\mathrm{~s}$, $\left.3 \mathrm{H}, \mathrm{OCH}_{3}\right), 7.12-7.14(\mathrm{~d}, J=7.2 \mathrm{~Hz}, 2 \mathrm{H}, \mathrm{Ar}-\mathrm{CH}), 7.52-7.54(\mathrm{~d}, J=7.2 \mathrm{~Hz}, 2 \mathrm{H}, \mathrm{Ar}-\mathrm{CH}), 7.78(\mathrm{~s}, 1 \mathrm{H}$, $=\mathrm{CH}), 9.70(\mathrm{~s}, 1 \mathrm{H}, \mathrm{NH}), 11.74(\mathrm{~s}, 2 \mathrm{H}, \mathrm{COOH}) .{ }^{13} \mathrm{C} \mathrm{NMR}: \delta \mathrm{ppm}=35.9,53.2,55.3,114.7,127.5,128.8$, $132.5,135.6,152.9,158.3,167.2,172.2,178.2$.

4.3.2.10. (Z)-2-((5-(4-methoxybenzylidene)-4-oxo-4,5-dihydrothiazol-2-yl)amino)-3-(1H-imidazol4-yl)propanoic acid (6j)

Yellow solid, Yield: 98\%, mp 198-200 ${ }^{\circ} \mathrm{C}$; ES-MS m/z: 372.40. IR vmax $/ \mathrm{cm}^{-1}: 3442$ (OH), 3296 $(\mathrm{NH}), 2921(\mathrm{CH}-\mathrm{Ar}), 1693(\mathrm{C}=\mathrm{O}), 1500(\mathrm{C}=\mathrm{C}), 1455(\mathrm{C}=\mathrm{N}), 1015(\mathrm{C}-\mathrm{S}), 824(\mathrm{C}-\mathrm{N}) .{ }^{1} \mathrm{H}$ NMR $(400$ $\left.\mathrm{MHz}, \mathrm{DMSO}-\mathrm{d} 6, \mathrm{ppm}^{\prime}=3.10\left(\mathrm{~s}, 2 \mathrm{H}, \mathrm{CH}_{2}\right), 3.60(\mathrm{~s}, 1 \mathrm{H}, \mathrm{CH}), 3.82\left(\mathrm{~s}, 3 \mathrm{H}, \mathrm{OCH}_{3}\right),\right), 7.10-7.12(\mathrm{~d}, J=$ $7.2 \mathrm{~Hz}, 2 \mathrm{H}, \mathrm{Ar}-\mathrm{CH}), 7.30-7.32(\mathrm{~d}, J=7.2 \mathrm{~Hz}, 2 \mathrm{H}, \mathrm{Ar}-\mathrm{CH}), 7.64(\mathrm{~s}, 1 \mathrm{H},=\mathrm{CH}$ imidazole ring $), 7.80$ $(\mathrm{s}, 1 \mathrm{H},=\mathrm{CH}), 8.64(\mathrm{~s}, 1 \mathrm{H},=\mathrm{CH}$ imidazole ring $), 8.70(\mathrm{~s}, 2 \mathrm{H}, \mathrm{NH}), 10.90(\mathrm{~s}, 1 \mathrm{H}, \mathrm{COOH}) .{ }^{13} \mathrm{C}$ NMR: $\delta \mathrm{ppm}=28.9,58.3,117.9,55.2,114.5,124.7,127.9,128.4,129.2,132.1,135.2,152.3,159.2,168.5$, 175.2 .

\subsubsection{1. (Z)-2-((5-(4-methoxybenzylidene)-4-oxo-4,5-dihydrothiazol-2-yl)amino)-3-(4-} hydroxyphenyl) propanoic acid (6k)

Yellow solid, Yield: 98\%, mp 157-159 ${ }^{\circ} \mathrm{C}$; ES-MS m/z: 398.43. IR vmax /cm ${ }^{-1}: 3445(\mathrm{O}=\mathrm{C}-\mathrm{OH}), 3393$ $(\mathrm{OH}), 3214(\mathrm{NH}), 2974(\mathrm{CH}-\mathrm{Ar}), 1731(\mathrm{HO}-\mathrm{C}=\mathrm{O}), 1699(\mathrm{C}=\mathrm{O}), 1543(\mathrm{C}=\mathrm{C}), 1591(\mathrm{C}=\mathrm{N}), 1011(\mathrm{C}-$ $\mathrm{S}), 1082(\mathrm{C}-\mathrm{N}) .{ }^{1} \mathrm{H}$ NMR $(400 \mathrm{MHz}, \mathrm{DMSO}-\mathrm{d} 6, \mathrm{ppm})=2.80-2.82\left(\mathrm{~d}, 2 \mathrm{H}, \mathrm{CH}_{2}\right), 3.80\left(\mathrm{~s}, 3 \mathrm{H}, \mathrm{OCH}_{3}\right)$, 4.40-4.42 (t, 1H, CH), 5.32 (s, 1H, OH), 7.10-7.12 (d, $J=7.6 \mathrm{~Hz}, 4 \mathrm{H}, \mathrm{Ar}-\mathrm{CH}), 7.50-7.52(\mathrm{~d}, J=7.6$ $\mathrm{Hz}, 4 \mathrm{H}, \mathrm{Ar}-\mathrm{CH}), 7.72(\mathrm{~s}, 1 \mathrm{H},=\mathrm{CH}), 9.32(\mathrm{~s}, 1 \mathrm{H}, \mathrm{NH}), 11.16(\mathrm{~s}, 1 \mathrm{H}, \mathrm{COOH}) .{ }^{13} \mathrm{C} \mathrm{NMR}: \delta \mathrm{ppm}=36.4$, $55.6,56.6,115.9,127.7,128.6,128.9,129.2,130.2,135.3,152.2,155.7,158.5,167.7,174.2$.

\subsubsection{2. (Z)-2-((5-(4-methoxybenzylidene)-4-oxo-4,5-dihydrothiazol-2-yl)amino)-3-hydroxy} butanoic acid (6l)

Yellow solid, Yield: $98 \%$, mp 181-183 ${ }^{\circ} \mathrm{C}$; ES-MS m/z: 336.36. IR vmax $/ \mathrm{cm}^{-1}: 3454(\mathrm{OH}), 3212$ $(\mathrm{NH}), 3012(\mathrm{CH}-\mathrm{Ar}), 1733(\mathrm{HO}-\mathrm{C}=\mathrm{O}), 1691(\mathrm{C}=\mathrm{O}), 1555(\mathrm{C}=\mathrm{C}), 1597(\mathrm{C}=\mathrm{N}), 1046(\mathrm{C}-\mathrm{S}), 1112(\mathrm{C}-$ N). ${ }^{1} \mathrm{H}$ NMR $\left(400 \mathrm{MHz}, \mathrm{DMSO}-\mathrm{d} 6, \mathrm{ppm}^{2}=1.15-1.17\left(\mathrm{~d}, 3 \mathrm{H}, \mathrm{CH}_{3}\right), 3.50-3.52(\mathrm{~d}, 1 \mathrm{H}, \mathrm{CH}), 3.60(\mathrm{~s}\right.$, $1 \mathrm{H}, \mathrm{OH}), 3.80\left(\mathrm{~s}, 3 \mathrm{H}, \mathrm{OCH}_{3}\right), 3.93-3.95(\mathrm{~m}, 1 \mathrm{H}, \mathrm{CH}), 7.20-7.22(\mathrm{~d}, J=7.2 \mathrm{~Hz}, 2 \mathrm{H}, \mathrm{Ar}-\mathrm{CH}), 7.50-$ 
$7.652(\mathrm{~d}, J=7.2 \mathrm{~Hz}, 2 \mathrm{H}, \mathrm{Ar}-\mathrm{CH}), 7.74(\mathrm{~s}, 1 \mathrm{H},=\mathrm{CH}), 9.68(\mathrm{~s}, 1 \mathrm{H}, \mathrm{NH}), 11.24(\mathrm{~s}, 1 \mathrm{H}, \mathrm{COOH}) .{ }^{13} \mathrm{C}$ NMR: $\delta$ ppm $=19.7,55.6,56.6,64.4,127.8,128.7,128.9,132.4,135.1,152.9,158.2,167.8,175.2$.

\section{References}

1. Luzina E. L., Popov A. V. (2009) Synthesis and anticancer activity of Nbis(trifluoromethyl)alkyl-N'-thiazolyl and N-bis(trifluoromethyl)alkyl-N'-benzothiazolyl ureas. Eur. J. Med. Chem. 44, 4944-4953.

2. Carradori S., Secci D., Bolasco A., De Monte C., Yanez M. (2012) Synthesis and selective inhibitory activity against human COX-1 of novel 1-(4-substituted-thiazol-2-yl)-3,5di(hetero)aryl-pyrazoline derivatives. Arch. Pharm. 345, 973-979.

3. Holla B.S., Malini K.V., Rao B.S., Sarojini B.K., Kumari N.S. (2003) Synthesis of some new 2,4-disubstituted thiazoles as possible antibacterial and anti-inflammatory agents. Eur. J. Med. Chem. 38, 313-318.

4. Toyoshi K., Misako A., Masako K., Katsuya O., Shigekatsu K., Tamatsu M., Takeshi I. (1985) Syntheses and Antiinflammatory Activity of Malonamic Acid, Malonamate and Malonamide Derivatives of Some Heterocyclic Compounds. Chem. Pharm. Bull. 33, 4878-4888.

5. Murugan R., Anbazhagan S., Lingeshwaran S., Narayanan S., (2009) Corrigendum to "Synthesis and in vivo antidiabetic activity of novel dispiropyrrolidines through [3+2] cycloaddition reactions with thiazolidinedione and rhodanine derivatives. Eur. J. Med. Chem. 44, 3272-3279.

6. Chandrappa S., Kavitha C.V., Shahabuddin M. S., Vinaya K., Ananda C. S., Ranganatha S. R., Raghavan S. C., Rangappa K. S. (2009) Synthesis of 2-(5-((5-(4-chlorophenyl)furan-2-yl) methylene)-4-oxo-2-thioxothiazolidin-3-yl)acetic acid derivatives and evaluation of their cytotoxicity and induction of apoptosis in human leukemia cells. Bioorg. Med. Chem. 17, 25762584.

7. Brooke E. W., Davies S. G., Mulvaney A.W., Okada M., Pompeo F., Sim E., Vickers R. J., Westwood I. M. (2003) Synthesis and in vitro evaluation of novel small molecule inhibitors of bacterial arylamine N-acetyltransferases (NATs). Bioorg. Med. Chem. 13, 2527-2530.

8. Mallikarjuna B. P., Sastry B. S., Suresh G. V., Rajendra prasad Y., Chandrashekar S. M., Sathisha K. (2009) Synthesis of new 4-isopropylthiazole hydrazide analogs and some derived clubbed triazole, oxadiazole ring systems--a novel class of potential antibacterial, antifungal and antitubercular agents. Eur. J. Med. Chem. 44, 4739-4746.

9. Balzarini J., Orzeszko B., Maurin J. K., Orzeszko A. (2007) Synthesis and anti-HIV studies of 2-adamantyl-substituted thiazolidin-4-ones. Eur. J. Med. Chem. 42, 993-1003.

10. Murugesan V., Tiwari V.S., Saxena R., Tripathi R., Paranjape R., Kulkarni S., Makwana N., Suryawanshi R., Katti S. B. (2011) Lead optimization at C-2 and N-3 positions of thiazolidin4-ones as HIV-1 non-nucleoside reverse transcriptase inhibitors. Bioorg. Med. Chem. 19, 69196926.

11. Rawal R. K., Tripathi R., Katti S. B., Pannecouque C., Clercq E. D. (2007) Synthesis and evaluation of 2-(2,6-dihalophenyl)-3-pyrimidinyl-1,3-thiazolidin-4-one analogues as anti-HIV1 agents. Bioorg. Med. Chem. 15, 3134-3142.

12. Zhang X., Li X., Li D., Qua G., Wang J., Loiseau P. M., Fan X. (2009) Ionic Liquid Mediated and Promoted Eco-Friendly Preparation of Thiazolidinone and Pyrimidine NucleosideThiazolidinone Hybridsand Their Antiparasitic Activities. Bioorg. Med. Chem. Lett. 19, 62806283.

13. Verma A., Saraf S. K. (2008) 4-thiazolidinone-A biologically active scaffold. Eur. J. Med. Chem. 43, 897-905.

14. Gouveia F. L., de Oliveira R. M. B., de Oliveira T. B., da Silva I.M., do Nascimento S. C., de Sena K. X. F. R., de Albuquerque J. F. C. (2009) Synthesis, antimicrobial and cytotoxic activities of some 5-arylidene-4-thioxo-thiazolidine-2-ones. Eur. J. Med. Chem. 44, 2038-2043. 
15. Ottana R., Carotti S., Maccari R., Landini I., Chiricosta G., Caciagli B., Vigorita M. G., Mini E., (2005) In vitro antiproliferative activity against human colon cancer cell lines of representative 4-thiazolidinones. Part I. Bioorg. Med. Chem. Lett. 15, 3930-3933.

16. Shah T. J., Desai V. A. (2007) Synthesis of some novel fluorinated 4-thiazolidinones containing

17. amide linkages and their antimicrobial screening. ARKIVOC, 14, 218-228.

18. Gualtieri M., Bastide L., Latouche P. V., Leonette J. P. (2006) In-vitro activity of a new antibacterial rhodanine derivative against Staphylococcus epidermidis biofilms. J. Antimicrob. Chemother. 58, 778-783.

19. Sim M. M., Ng S. B., Buss A. D., Crasta S. C., Goh K. L., Lee S. K. (2002) Benzylidene rhodanines as novel inhibitors of UDP-N-acetylmuramate/l-alanine ligase. Bioorg. Med. Chem. Lett. 12, 697-699.

20. Petrikaite V., Tarasevicius E., Pavilonis A. (2007) New ethacridine derivatives as the potential antifungal and antibacterial preparations. Medicina (Kaunas) 43, 657-663.

21. Sortino M., Delgado P., Juarez S., Quiroga J., Abonia R., Insuasty B., Nogueras M., Rodero L., Garibotto F. M., Enriz R. D., Zacchino S. A. (2007) Synthesis and antifungal activity of (Z)5-arylidenerhodanines. Bioorg. Med. Chem. 15, 484-494.

22. Jin X., Zheng C. J., Song M. X., Wu Y., Sun L. P., Li Y. J., Yu L. J., Piao H. R., (2012) Synthesis and antimicrobial evaluation of L-phenylalanine-derived C5-substituted rhodanine and chalcone derivatives containing thiobarbituric acid or 2-thioxo-4-thiazolidinone. Eur. J. Med. Chem. 56, 203-209.

23. Coulibaly W. K., Paquin L., Benie A., Bekro Y. A., Durieux E., Meijer L., Guevel R. L., Corlu A., Bazureau J. P. (2012) Synthesis of New N,N'-Bis(5-arylidene-4-oxo-4,5-dihydrothiazolin2-yl)piperazine Derivatives Under Microwave Irradiation and Preliminary Biological Evaluation. Sci. Pharm. 80, 825-836.

24. Kaminskyy D., Khyluk D., Vasylenko O., Lesyk R. (2012) An Efficient Method for the Transformation of 5-Ylidenerhodanines into 2,3,5-Trisubstituted-4-thiazolidinones. Tetrahedron Lett. 53, 557-559.

25. Guernon J. M., Wu Y. J. (2011) 3-Bromocyclohexane-1,2-dione as a useful reagent for Hantzsch synthesis of thiazoles and the synthesis of related heterocycles. Tetrahedron Lett. 52, 3633-3635.

26. Khaligh N.G., Shirini F. (2014) Ultrasound assisted the chemoselective 1,1-diacetate protection and deprotection of aldehydes catalyzed by poly(4-vinylpyridinium)hydrogen sulfate salt as a eco-benign, efficient and reusable solid acid base. Ultrason. Sonochem. 20, 19-25.

27. Li J.T., Yin Y., Li L., Sun M. X. (2010) A convenient and efficient protocol for the synthesis of 5-aryl-1,3-diphenylpyrazole catalyzed by hydrochloric acid under ultrasound irradiation. Ultrason. Sonochem. 17, 11-13.

28. Srivastava R. M., Filho R. A., Silva C. A., Bortoluzzi A. (2009) First ultrasound-mediated onepot synthesis of N-substituted amides. Ultrason. Sonochem. 16, 737-742.

29. Prasad K., Pinjari D. V., Pandit A.B., Mhaske S. T. (2010) Phase transformation of nanostructured titanium dioxide from anatase-to-rutile via combined ultrasound assisted sol-gel technique. Ultrason. Sonochem. 17, 409- 415.

30. Jarag K. J., Pinjari D. V., Pandit A. B., Shankarling G.S. (2011) Synthesis of chalcone (3-(4fluorophenyl)-1-(4-methoxyphenyl)prop-2-en-1-one): advantage of sonochemical method over conventional method. Ultrason. Sonochem. 18, 617-623.

31. Fu L. H., Dong Y. Y., Ma M. G., Li S. M., Sun R. C. (2014) Compare study CaCO3 crystals on the cellulose substrate by microwave-assisted method and ultrasound agitation method. Ultrason. Sonochem. 20, 839-845.

32. Suslick K. S., Choe S. B., Cichowlas A. A., Grinstaff M. W. (1991) Sonochemical synthesis of amorphous iron. Nature 353, 414-416.

33. Bretanha L. C., Teixeira V. E., Ritter M., Siqueira G. M., Cunico W., Pereira C. M. P., Freitag R. A. (2007) Ultrasound-promoted synthesis of 3-trichloromethyl-5-alkyl(aryl)-1,2,4oxadiazoles. Ultrason. Sonochem. 18, 704-707. 
34. Duarte A., Cunico W., Pereira C. M. P., Flores A. F. C., Freitag R. A., Siqueira G. M. (2010) Ultrasound promoted synthesis of thioesters from 2-mercaptobenzoxa(thia)zoles. Ultrason. Sonochem. 17, 281-283.

35. Lorimer J. P., Mason T. J. (1987) sonochemistry part 1- The physical aspects, Chem. Soc. Rev. 16, 239-274.

36. Pansare D. N., Shelke R. N., Pawar C. D. (2017) A facile synthesis of (Z)-2-((5-(4chlorobenzylidene)-4-oxo-4,5-dihydrothiazol-2-yl)amino)substituted acid using microwave irradiation and conventional method. Lett. Org. Chem. 14(7), 517-524.

37. Pansare D. N., Shelke R. N., Shinde D. B. (2017) A facial synthesis and anticancer activity of (Z)-2-((5-(4-nitrobenzylidene) -4-oxo-4,5-dihydrothiazol-2-yl)amino) substituted acid. J. Het. Chem. 54(6), 3077-3086.

38. Pansare D. N., Shinde D. B. (2017) A facile synthesis of novel series (Z)-2-((4-oxo-5(thiophen-2-yl methylene)-4,5-dihydro thiazol-2-yl)amino) substituted acid. J. Saudi. Chem. Soc. 21, 434-440.

39. Pansare D. N., Shinde D. B. (2015) Synthesis and Antimicrobial Activity of new (Z)-2-((5-(4Hydroxybenzylidene)-4-Oxo-4,5-Dihydrothiazol-2-Y1)Amino) Acid and its Derivatives. Res. Rev. J. Chem. 4(1), 1-7.

40. Pawar C. D., Chavan, S. L., Pawar U. D., Pansare D. N., Deshmukh S. V., Shinde D. B. (2018) Synthesis, anti-proliferative activity, SAR and Kinase inhibition studies of thiazol-2-ylsubstituted sulfonamide derivatives. J. Chin. Chem. Soc. DOI- 10.1002/jccs.201800312

41. Pawar C. D., Pansare D. N., Shinde D. B. (2018) (Substituted)-benzo[b]thiophene-4carboxamide synthesis and anti-proliferative activity study. Lett. Drug. Des. Disc. DOI$10.2174 / 1570180815666181004114125$

42. Pawar C. D., Pansare D. N., Shinde D. B. (2018) Synthesis of new 3-(substituted phenyl)-N-(2hydroxy-2-(substituted phenyl)ethyl)-N-methylthiophene-2-sulfonamide derivatives as antiproliferative agents. Eur. J. Chem. 9(1), 13-21.

43. Pawar C. D., Pansare D. N., Shinde D. B., (2017) Synthesis and antiproliferative activity of 3(substituted)-4,5,6,7-tetrahydro-6-(substituted)-1H-pyrazolo[3,4-c]pyridine Derivatives. Eur. J. Chem. 8(4). 400-409.

44. Pawar C. D., Sarkate A. P., Karnik K. S., Bahekar S. S., Pansare D. N., Shelke R. N., Jawale C. S., Shinde D. B. (2016) Synthesis and antimicrobial evaluation of novel ethyl 2-(2-(4substituted) acetamido)-4-subtituted-thiazole-5-carboxylate derivatives. Bioorg. Med. Chem. Lett., 26, 3525-3528.

45. Pawar C. D., Sarkate A. P., Karnik K. S., Pansare D. N., Shinde D. B. (2017) Synthesis and antiproliferative evaluation of new (4-substituted-3,4-dihydro-2H-benzo[b][1,4]oxazin-2yl)methane substituted sulfonamide derivatives. Eur. J. Chem. 8, 384 - 390.

46. Sarkate A. P., Pansare D. N., Kale I., Bahekar S. S., Shinde D. B. (2017) Microwave assisted copper-catalyzed synthesis of substituted benzamides through decarboxylative C-N cross coupling. Curr. Micro. Chem. 4, 163-167

47. Sarkate A. P., Pansare D. N., Kale I, Shinde D. B. (2017) Microwave and Conventional Method Assisted Synthesis of 2-(substituted) -3-(4-methoxybenzyl) Thiazolidin-4-ones Using $\mathrm{ZrOCl} 2 \cdot 8 \mathrm{H} 2 \mathrm{O}$ as a Base. Curr. Micro. Chem. 4(2), 139-145.

48. Shelke R. N., Pansare D. N., Pawar C. D., Pawar R. P., Bembalkar S. R. (2017) Synthesis of $3 \mathrm{H}$-imidazo[4,5-b] pyridine with evaluation of their anticancer and antimicrobial activity. Eur. J. Chem. 8(1), 25-32. 


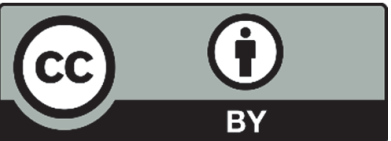

(C) 2019 by the authors; licensee Growing Science, Canada. This is an open access article distributed under the terms and conditions of the Creative Commons Attribution (CC-BY) license (http://creativecommons.org/licenses/by/4.0/). 